University of Wollongong

Research Online

Faculty of Engineering - Papers (Archive)

Faculty of Engineering and Information

Sciences

March 2003

\title{
Modelling of prefabricated vertical drains in soft clay and evaluation of their effectiveness in practice
}

Buddhima Indraratna

University of Wollongong, indra@uow.edu.au

C. Bamunawita

Coffey Geosciences, Australia

I. Redana

University of Wollongong

G. Mclntosh

Douglaspartners, Australia

Follow this and additional works at: https://ro.uow.edu.au/engpapers

Part of the Engineering Commons

https://ro.uow.edu.au/engpapers/394

\section{Recommended Citation}

Indraratna, Buddhima; Bamunawita, C.; Redana, I.; and McIntosh, G.: Modelling of prefabricated vertical drains in soft clay and evaluation of their effectiveness in practice 2003.

https://ro.uow.edu.au/engpapers/394

Research Online is the open access institutional repository for the University of Wollongong. For further information contact the UOW Library: research-pubs@uow.edu.au 


\title{
Modelling of prefabricated vertical drains in soft clay and evaluation of their effectiveness in practice*
}

\author{
B. INDRARATNA, ${ }^{*}$ C. BAMUNAWITA, ${ }^{*}$ I. W. REDANA ${ }^{\dagger}$ and G. McINTOSH ${ }^{*}$ \\ ${ }^{*}$ Civil Engineering Discipline, University of Wollongong, Australia; ${ }^{\dagger}$ Department of Civil \\ Engineering, Udayana University, Bali, Indonesia; 'Douglas Partners Pty Ltd, Unanderra, \\ Australia
}

Prefabricated vertical band drains are rapidly increasing in popularity as one of the most cost-effective soft clay improvement techniques worldwide. Nevertheless, problems caused during installation (such as the smear effect), drain clogging and well resistance of long drains contribute to retarded pore pressure dissipation, making these drains less effective in the field. This leads to reduced settlement compared with that which would be expected from ideal drains. This paper is an attempt to discuss, comprehensively, the modelling aspects of prefabricated vertical drains and to interpret the actual field data measured in a number of case studies that demonstrate their advantages and drawbacks. Both analytical and numerical modelling details are elucidated, based on the authors' experience and other research studies. Where warranted, laboratory data from large-scale experimental facilities are highlighted.

\section{Introduction}

In South-East Asia during the past decade or two, the rapid increase in population and associated development activities have resulted in the reclamation of coastal zones and the utilisation of other low-lying soft clay land for construction. Industrial, commercial and residential construction sites are often challenged by the low-lying marshy land, which comprises compressible clays and organic peat of varying thickness. When such areas of excessive settlement are selected for development work, it is essential to use fill to raise the ground above the flood level. Damage to structures can be caused by unacceptable differential settlement, which may occur because of the heterogeneity of the fill and the compressibility of the underlying soft soils.

It has been common practice to overcome distress in structures, including road and rail embankments built on filled land, by supporting them on special piled foundations. However, depending on the depth of the strong bearing

(GI 1143) Paper received 5 March 2002; accepted 16 December 2002 * This paper was initially presented at the $4^{\text {th }}$ International con-
ference on Ground Improvement Techniques 2002, Kuala Lumpur.
Les drains verticaux préfabriqués deviennent de plus en plus populaires car ils forment l'une des techniques des plus rentables d'amélioration de l'argile tendre. Néanmoins, les problèmes causés pendant l'installation (comme l'effet de rémanence), l'occlusion des drains et la résistance des puits dans le cas de drains longs, contribuent à retarder la dissipation de pression interstitielle, ce qui rend ces drains moins efficaces sur le terrain. Ceci cause un tassement inférieur à celui qu'on attend normalement de drains parfaits. Cette étude essaie d'évaluer, de manière globale, les aspects de modélisation de drains verticaux préfabriqués et d'interpréter les données réelles relevées sur le terrain dans un certain nombre d'études de cas qui montrent leurs avantages et leurs inconvénients. Nous expliquons les détails de la modélisation analytique et numérique en nous basant sur notre expérience ainsi que sur $d^{\prime}$ autres recherches. Partout où cela est nécessaire, nous donnons aussi les données relevées en laboratoire dans une installation expérimentale grandeur nature.

stratum, the cost of piling can become prohibitively high. A more economically attractive alternative to the use of piled foundations is improvement of the engineering properties of the underlying soft soils. Preloading with vertical drains is a successful ground improvement technique, which involves the loading of the ground surface to induce a greater part of the ultimate settlement of the underlying soft strata. In other words, a surcharge load equal to or greater than the expected foundation loading is applied to accelerate consolidation by rapid pore pressure dissipation via vertical drains. Vertical drains are applicable for moderately to highly compressible soils, which are usually normally consolidated or lightly overconsolidated, and for stabilising a deep layer of soft clay having a low permeability.

In 1940, prefabricated band-shaped drains (PVDs) and Kjellman cardboard wick drains were introduced in ground improvement. Several other types of PVD have been developed since then, such as Geodrain (Sweden), Alidrain (England), and Mebradrain (Netherlands). PVDs consist of a perforated plastic core functioning as a drain, and a protective sleeve of fibrous material as a filter around the core. The typical size of band drains is usually in the order of $3.5 \mathrm{~mm} \times 100 \mathrm{~mm}$.

The vertical drains are generally installed using one of two different methods, either dynamic or static. In the dynamic method a steel mandrel is driven into the ground 
using either a vibrating hammer or a conventional drop hammer. In the static method the mandrel is pushed into the soil by means of a static force. Although the dynamic method is quicker, it causes more disturbance of the surrounding soil during installation. It results in shear strain accompanied by an increase in total stress and pore water pressure, in addition to the displacement of the soil surrounding the vertical drain.

\section{Factors influencing PVD efficiency}

\section{I Smear zone}

The extent of the smear zone is a function of the size and shape of the mandrel. The installation of PVDs by a mandrel causes significant remoulding of the subsoil, especially in the immediate vicinity of the mandrel. Barron (1948) and Hansbo (1981) modelled the smear zone by dividing the soil cylinder dewatered by the central drain into two zones: the disturbed or smear zone in the immediate vicinity of the drain, and the undisturbed region outside the smear zone. Onoue et al. (1991) introduced a three-zone hypothesis defined by:

(a) the plastic smear zone in the immediate vicinity of the drain, where the soil is significantly remoulded during the process of installation of the drain

(b) the plastic zone where the permeability is moderately reduced

(c) the undisturbed zone where the soil is unaffected.

The size of the smear zone has been estimated by various researchers (Jamiolkowski and Lancellotta, 1981; Hansbo, 1987), who proposed that the smear zone diameter is two to three times the equivalent diameter of the mandrel (that is, a circle with equivalent cross-sectional area). Indraratna and Redana (1998) proposed that the estimated smear zone is three to four times the cross-sectional area of the mandrel, based on large-scale consolidometer testing (Fig. 1). Within the smear zone, the ratio $k_{\mathrm{h}} / k_{\mathrm{v}}$ can be approximated to unity (Hansbo, 1981; Bergado et al., 1991; Indraratna and Redana, 1998).

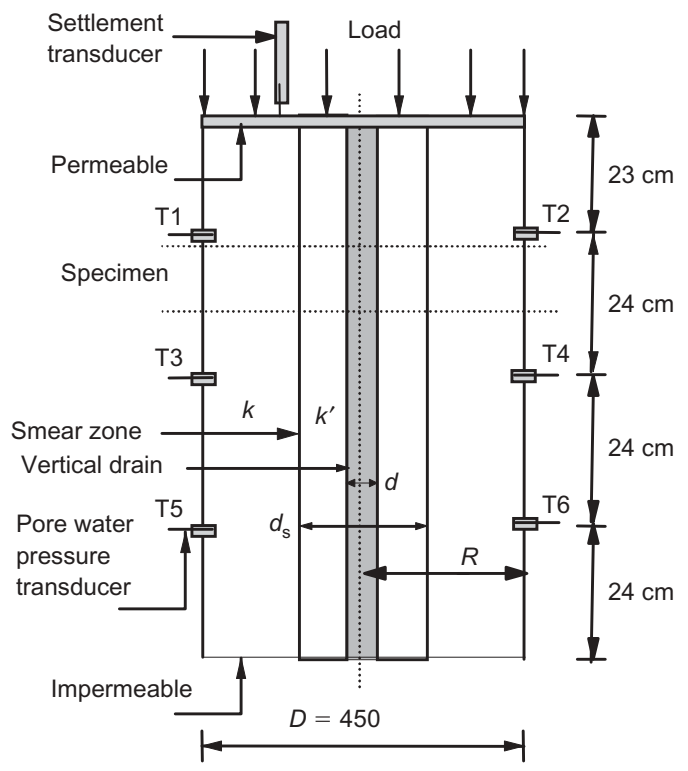

Fig. I. Schematic section of the large, radial consolidometer showing the central drain, and associated smear, settlement and pore water pressure transducers (Indraratna and Redana, 1998)

\section{Well resistance}

The well resistance (resistance to flow of water) increases with increase in the length of the drain, and reduces the consolidation rate. The well resistance retards pore pressure dissipation, and the associated settlement. The other main factors that increase well resistance are deterioration of the drain filter (reduction of drain cross-section), silt intrusion into the filter (reduction of pore space), and folding of the drain due to lateral movement.

\section{Analytical modelling of vertical drains}

\section{Historical development}

If the coefficient of consolidation in the horizontal direction is much higher than that in the vertical direction, then since vertical drains reduce the drainage path considerably in the radial direction, the effectiveness of PVDs in accelerating the rate of consolidation is remarkably improved. Barron (1948) presented the most comprehensive solution to the problem of radial consolidation by drain wells. He studied the two extreme cases of free strain and equal strain, and showed that the average consolidation obtained in these cases is nearly the same. Barron also considered the influence of well resistance and smear on the consolidation process due to vertical well drains. Richart (1959) presented a convenient design chart for the effect of smear, in which the influence of variable void ratio was also considered. A simplified analysis for modelling smear and well resistance was proposed by Hansbo $(1979,1981)$. Onoue et al. (1988) presented a more rigorous solution based on the free strain hypothesis. The Barron and Richart solutions for ideal drains (no smear, no well resistance) are given in standard soil mechanics text books under radial consolidation, with wellknown curves of degree of consolidation $\left(U_{\mathrm{v}}\right.$ and $\left.U_{\mathrm{h}}\right)$ plotted against the corresponding time factors $\left(T_{\mathrm{v}}\right.$ and $\left.T_{\mathrm{h}}\right)$ for various ratios of drain spacing to drain radius $(n)$.

\section{Approximate equal strain solution}

Hansbo (1981) proposed an approximate solution for vertical drains, based on the equal strain hypothesis, by taking both smear and well resistance into consideration. The rate of flow of internal pore water in the radial direction can be estimated by applying Darcy's law (Fig. 2). The total flow of water from the slice $\mathrm{d} z$ to the drain, $\mathrm{d} Q_{1}$, is equal to the change of flow of water from the surrounding soil, $\mathrm{d} Q_{2}$, which is proportional to the change of volume of the soil mass. The average degree of consolidation, $\bar{U}$, of the soil cylinder with a vertical drain is given by

$$
\begin{gathered}
\bar{U}_{\mathrm{h}}=1-\exp \left(-\frac{8 T_{\mathrm{h}}}{\mu}\right) \\
\mu=\ln \left(\frac{n}{s}\right)+\left(\frac{k_{\mathrm{h}}}{k_{\mathrm{h}}^{\prime}}\right) \ln (s)-0.75+\pi z(2 l-z) \frac{k_{\mathrm{h}}}{q_{\mathrm{w}}}
\end{gathered}
$$

The effect of smear only (no well resistance) is given by

$$
\mu=\ln \left(\frac{n}{s}\right)+\left(\frac{k_{\mathrm{h}}}{k_{\mathrm{h}}^{\prime}}\right) \ln (s)-0.75
$$

The effect of well resistance (no smear) is given by

$$
\mu \approx \ln (n)-0.75+\pi z(2 l-z) \frac{k_{\mathrm{h}}}{q_{\mathrm{w}}}
$$




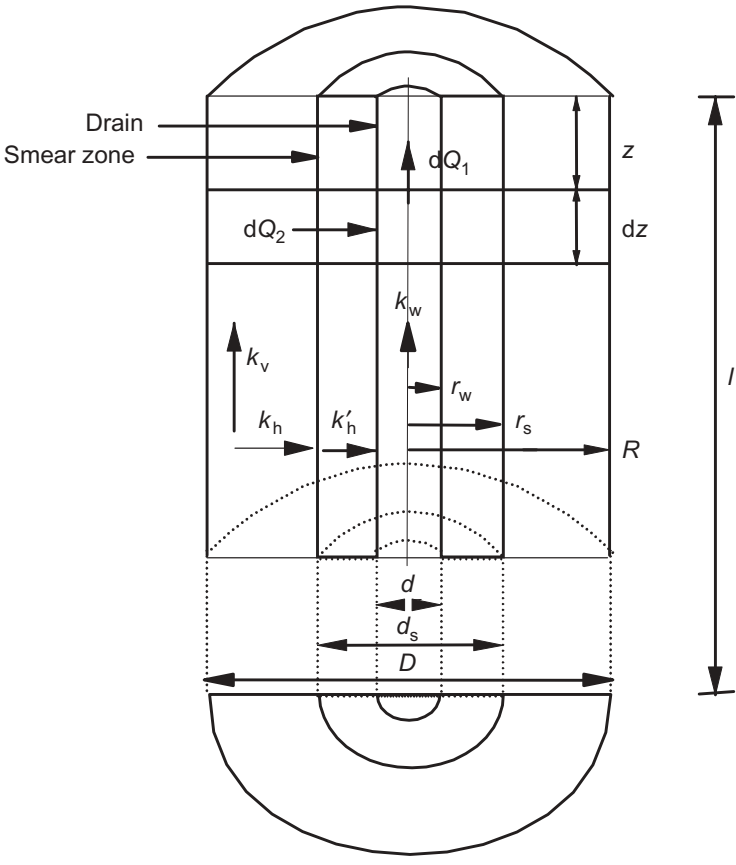

Fig. 2. Schematic of soil cylinder with vertical drain

For ideal drains (that is, both smear and well resistance are ignored), the last term in equation (3) also vanishes to give

$$
\mu=\ln (n)-0.75
$$

\section{Plane-strain consolidation model (Indraratna and Redana, 1997)}

Although each vertical drain is axisymmetric, most finiteelement analyses on embankments are conducted on the basis of the plane-strain assumption for computational efficiency. In order to employ a realistic two-dimensional finite-element analysis for vertical drains, the equivalence between the plane-strain and axisymmetric analyses needs to be established.

Equivalence between axisymmetric and plane-strain conditions can be achieved in three ways:

(a) geometric matching-the spacing of drains is matched while the permeability is kept the same

(b) permeability matching-the permeability coefficient is matched, while the drain spacing is kept the same

(c) a combination of the geometric and permeability and matching approaches-the plane-strain permeability is calculated for a convenient drain spacing.

Indraratna and Redana (1997) converted the vertical drain system into equivalent parallel drain elements by changing the coefficient of permeability of the soil, and by assuming the plane-strain cell to have a width of $2 B$ (Fig. 3). The halfwidth of the drains, $b_{\mathrm{w}}$, and the half-width of the smear zone, $b_{\mathrm{s}}$, are taken to be the same as their axisymmetric radii, $r_{\mathrm{w}}$ and $r_{\mathrm{s}}$ respectively, to give

$$
b_{\mathrm{w}}=r_{\mathrm{w}} \text { and } b_{\mathrm{s}}=r_{\mathrm{s}}
$$

The equivalent drain diameter, $d_{\mathrm{w}}$, or radius, $r_{\mathrm{w}}$, for band drains were determined by Hansbo (1979) based on perimeter equivalence to give

$$
d_{\mathrm{w}}=2 \frac{(a+b)}{\pi} \text { or } r_{\mathrm{w}}=\frac{(a+b)}{\pi}
$$

Considering the shape of the drain and the effective drainage area, Rixner et al. (1986) presented the equivalent
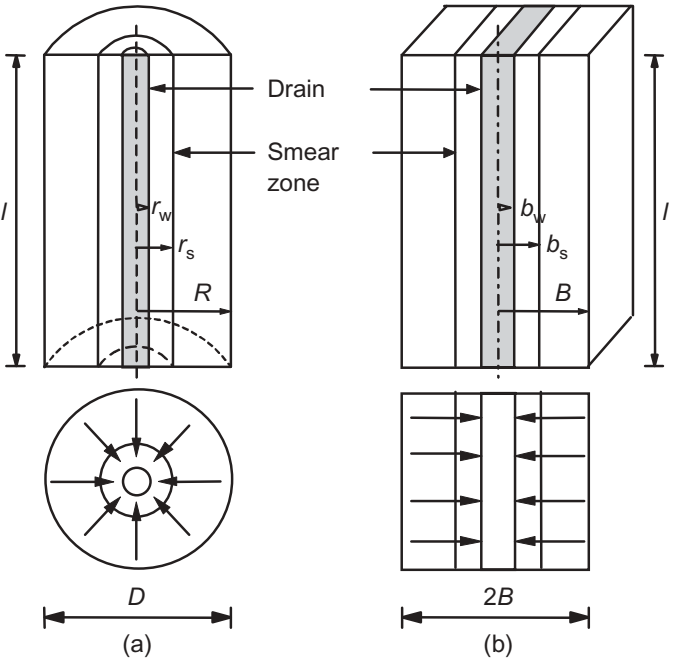

Fig. 3. Conversion of an axisymmetric unit cell into plane strain (Indraratna and Redana, 1997)

drain diameter, $d$, as the average of drain thickness and width:

$$
d=\frac{a+b}{2}
$$

where $a$ is the width of the PVD and $b$ is its thickness.

The average degree of consolidation in plane-strain conditions can now be represented by

$$
\bar{U}_{\mathrm{hp}}=1-\frac{\bar{u}}{\bar{u}_{0}}=1-\exp \left(\frac{-8 T_{\mathrm{hp}}}{\mu_{\mathrm{p}}}\right)
$$

where $\bar{u}_{0}$ is the initial pore pressure, $\bar{u}$ is the pore pressure at time $t$ (average values), and $T_{\mathrm{hp}}$ is the time factor in plane strain. If $k_{\mathrm{hp}}$ and $k_{\mathrm{hp}}^{\prime}$ are the undisturbed horizontal and corresponding smear zone permeabilities respectively, the value of $\mu_{\mathrm{p}}$ can be given by

$$
\mu_{\mathrm{p}}=\left[\alpha+(\beta) \frac{k_{\mathrm{hp}}}{k_{\mathrm{hp}}^{\prime}}+(\theta)\left(2 l z-z^{2}\right)\right]
$$

In the above equation, the geometric terms $\alpha$ and $\beta$, and the flow parameter $\theta$, are given by

$$
\begin{aligned}
& \alpha=\frac{2}{3}-\frac{2 b_{\mathrm{s}}}{B}\left(1-\frac{b_{\mathrm{s}}}{B}+\frac{b_{\mathrm{s}}^{2}}{3 B^{2}}\right) \\
& \beta=\frac{1}{B^{2}}\left(b_{\mathrm{s}}-b_{\mathrm{w}}\right)^{2}+\frac{b_{\mathrm{s}}}{3 B^{3}}\left(3 b_{\mathrm{w}}^{2}-b_{\mathrm{s}}^{2}\right) \\
& \theta=\frac{2 k_{\mathrm{hp}}^{2}}{k_{\mathrm{hp}}^{\prime} q_{\mathrm{z}} B}\left(1-\frac{b_{\mathrm{w}}}{B}\right)
\end{aligned}
$$

where $q_{\mathrm{z}}$ is the equivalent plane-strain discharge capacity.

For a given stress level and at each time step, the average degree of consolidation for axisymmetric $\left(\bar{U}_{\mathrm{h}}\right)$ and equivalent plane-strain $\left(\bar{U}_{\mathrm{hp}}\right)$ conditions are made equal:

$$
\bar{U}_{\mathrm{h}}=\bar{U}_{\mathrm{hp}}
$$

Equations (9) and (12) can now be combined with Hansbo's original theory (equation (1)) to determine the time factor ratio, as follows:

$$
\frac{T_{\mathrm{hp}}}{T_{\mathrm{h}}}=\frac{k_{\mathrm{hp}}}{k_{\mathrm{h}}} \frac{R^{2}}{B^{2}}=\frac{\mu_{\mathrm{P}}}{\mu}
$$

For simplicity, accepting the magnitudes of $R$ and $B$ to be the same, the following relationship between $k_{\mathrm{hp}}$ and $k_{\mathrm{hp}}^{\prime}$ can be derived: 


$$
k_{\mathrm{hp}}=\frac{k_{\mathrm{h}}\left[\alpha+(\beta) \frac{k_{\mathrm{hp}}}{k_{\mathrm{hp}}^{\prime}}+(\theta)\left(2 l z-z^{2}\right)\right]}{\left[\ln \left(\frac{n}{s}\right)+\left(\frac{k_{\mathrm{h}}}{k_{\mathrm{h}}^{\prime}}\right) \ln s-0 \cdot 75+\pi\left(2 l z-z^{2}\right) \frac{k_{\mathrm{h}}}{q_{\mathrm{w}}}\right]}
$$

If well resistance is ignored (that is, omit all terms containing $l$ and $z$ ), the influence of smear effect can be modelled by the ratio of the smear zone permeability to the undisturbed permeability:

$$
\frac{k_{\mathrm{hp}}^{\prime}}{k_{\mathrm{hp}}}=\frac{\beta}{\frac{k_{\mathrm{hp}}}{k_{\mathrm{h}}}\left[\ln \left(\frac{n}{s}\right)+\left(\frac{k_{\mathrm{h}}}{k_{\mathrm{h}}^{\prime}}\right) \ln s-0.75\right]-\alpha}
$$

For ideal drains, if both smear and well resistance effects are ignored, then equation (14) simplifies to the following expression, as proposed earlier by Hird et al. (1992):

$$
\frac{k_{\mathrm{hp}}}{k_{\mathrm{h}}}=\frac{0.67}{[\ln (n)-0.75]}
$$

The well resistance can be derived independently to obtain an equivalent plane-strain discharge capacity of drains (Hird et al., 1992), as given by

$$
q_{\mathrm{z}}=\frac{2}{\pi B} q_{\mathrm{w}}
$$

The above governing equations can be used in conjunction with finite-element analysis to execute numerical predictions of vertical drain behaviour, for both single-drain and multidrain conditions. For analysis of embankments with many PVDs, the above two-dimensional equivalent plane-strain solution works well for estimating settlement, pore pressures and lateral deformations.

\section{Basic features of PVD modelling}

\section{Equivalent drain diameter for band-shaped drain}

The conventional theory of consolidation assumes vertical drains that are circular in cross-section. Hence a bandshaped drain should be transformed to an equivalent circle, such that the equivalent circular drain has the same theoretical radial drainage capacity as the band-shaped drain. Based on the initial analysis of Kjellman (1948), Hansbo (1981) proposed the appropriate equivalent diameter, $d_{\mathrm{w}}$, for a prefabricated band-shaped drain (equation (7)), followed by another study (Rixner et al., 1986) that suggested a simpler value for $d_{\mathrm{w}}$ (equation (8)), as discussed earlier. Pradhan et al. (1993) suggested that the equivalent diameter of band-shaped drains should be estimated by considering the flow net around the soil cylinder of diameter $d_{\mathrm{e}}$ (Fig. 4). The mean square distance of the flow net is calculated as

$$
\bar{s}^{2}=\frac{1}{4} d_{\mathrm{e}}^{2}+\frac{1}{12} a^{2}-\frac{2 a}{\pi^{2}} \mathrm{~d}_{\mathrm{e}}
$$

On the basis of the above, the equivalent drain diameter is given by

$$
d_{\mathrm{w}}=\mathrm{d}_{\mathrm{e}}-2 \sqrt{\left(\bar{s}^{2}\right)}+b
$$

\section{Discharge capacity}

The discharge capacity of PVDs affects pore pressure dissipation, and it is necessary to analyse the well resistance factor. The discharge capacity, $q_{\mathrm{w}}$, of prefabricated vertical drains could vary from 100 to $800 \mathrm{~m}^{3}$ /year based on filter permeability, core volume or cross-section area, lateral

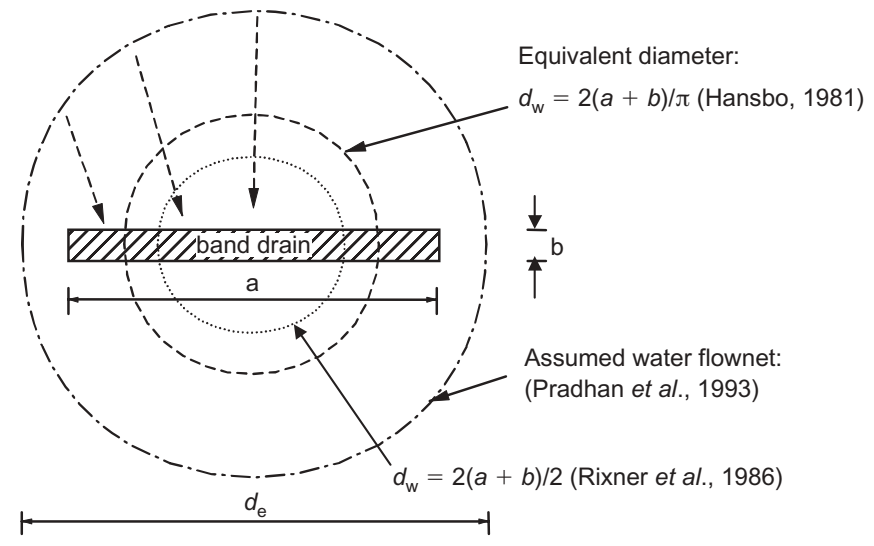

Fig. 4. Equivalent diameter of band-shaped vertical drain

confining pressure, and drain stiffness controlling its deformation characteristics, among other factors (Holtz et al., 1991). For long vertical drains that demonstrate high well resistance, the actual reduction of the discharge capacity can be attributed to:

(a) reduced flow in drain core due to increased lateral earth pressure

(b) folding and crimping of the drain due to excessive settlement

(c) infiltration of fine silt or clay particles through the filter (siltation).

Further details are given by Holtz et al. (1991).

As long as the initial discharge capacity of the PVD exceeds $100-150 \mathrm{~m}^{3}$ /year, some reduction in discharge capacity due to installation should not seriously influence the consolidation rates (Holtz et al., 1988). For synthetic drains affected by folding, compression and high lateral pressure, $q_{\mathrm{w}}$ values may be reduced to $25-100 \mathrm{~m}^{3} /$ year (Holtz et al., 1991). Based on the authors' experience, $q_{\mathrm{w}}$ values of $40-60 \mathrm{~m}^{3} /$ year are suitable for modelling most field drains affected by well resistance, and clogged PVDs are characterised by $q_{\mathrm{w}}$ approaching zero (Redana, 1999).

\section{Influence zone of drains}

The influence zone, $D$, is a function of the drain spacing, $S$, as given by

$$
D=1 \cdot 13 S
$$

for drains installed in a square pattern, and

$$
D=1 \cdot 05 S
$$

for drains installed in a triangular pattern. A square pattern of drains may be easier to install in the field, but a triangular layout provides more uniform consolidation between drains than a square pattern.

\section{Effect of drain unsaturation}

As a result of the installation process, air can be trapped in the annular space between the drain and the soil. Unless the soil is highly plastic, with a very high water content (dredged mud, for example), there is a possibility of having an annular space partially filled with trapped air (an air gap) upon withdrawal of the mandrel. This results in a situation where the inflow of water into the drain becomes retarded. In the numerical analysis, it can be assumed that the PVD and the air gap together constitute an unsaturated vertical interface, having a thickness equal to that of the 
mandrel. Fig. 5 shows the variation of drain saturation with respect to time (initial degree of saturation of $50 \%$ for a $1 \mathrm{~m}$ length), and Fig. 6 shows the effect on consolidation curves, for varying levels of saturation.

\section{Salient aspects of numerical modelling}

\section{Effect of horizontal to vertical permeability ratio}

The permeability characteristics of a number of intact clays have been reported by Tavenas et al. (1983). In these tests the horizontal permeability was also determined using samples rotated horizontally $\left(90^{\circ}\right)$ and of intermediate inclination $\left(45^{\circ}\right)$. For some marine clays (Champlain sea formation, Canada), the anisotropy ratio $\left(r_{\mathrm{k}}=k_{\mathrm{h}} / k_{\mathrm{v}}\right)$ estimated using the modified oedometer test was found to vary between 0.91 and 1.42. According to the experimental results plotted in Fig. 7 (Indraratna and Redana, 1995), the value of $k_{\mathrm{h}}^{\prime} / k_{\mathrm{v}}^{\prime}$ in the smear zone varies between 0.9 and 1.3 (average of 1.15). For the undisturbed soil (outside the smear zone), it is observed that the value of $k_{\mathrm{h}} / k_{\mathrm{v}}$ varies between 1.4 and $1 \cdot 9$, with an average of 1.63 . Shogaki et al. (1995) reported that the average values of $k_{\mathrm{h}} / k_{\mathrm{v}}$ were in the range 1.36 1.57 for undisturbed isotropic soil samples taken from

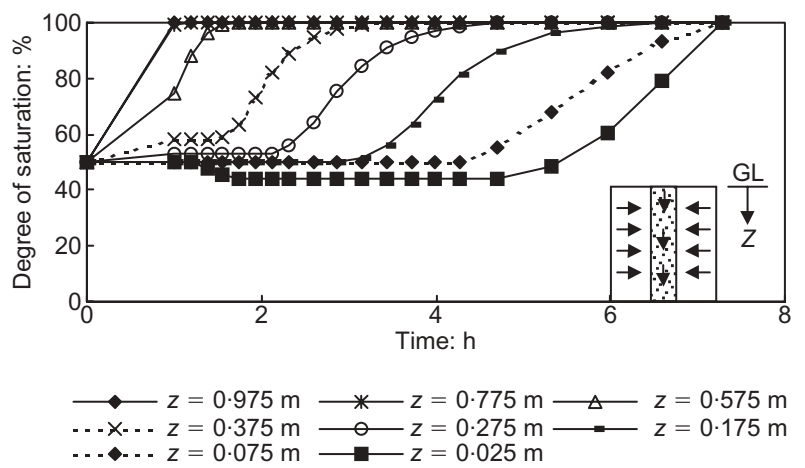

Fig. 5. Variation of drain saturation with time

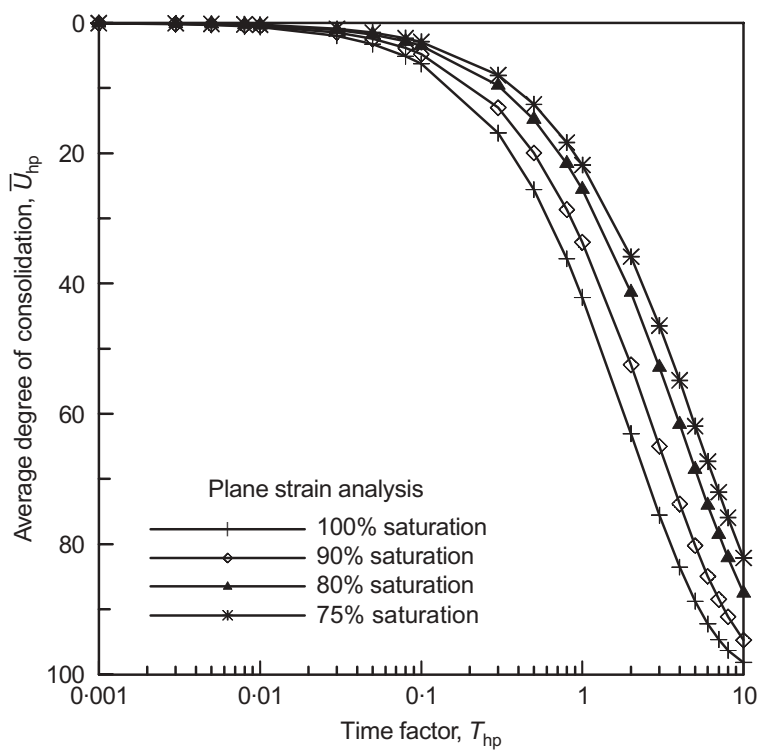

Fig. 6. Variation of degree of consolidation due to drain unsaturation (Indraratna et al., 200I)

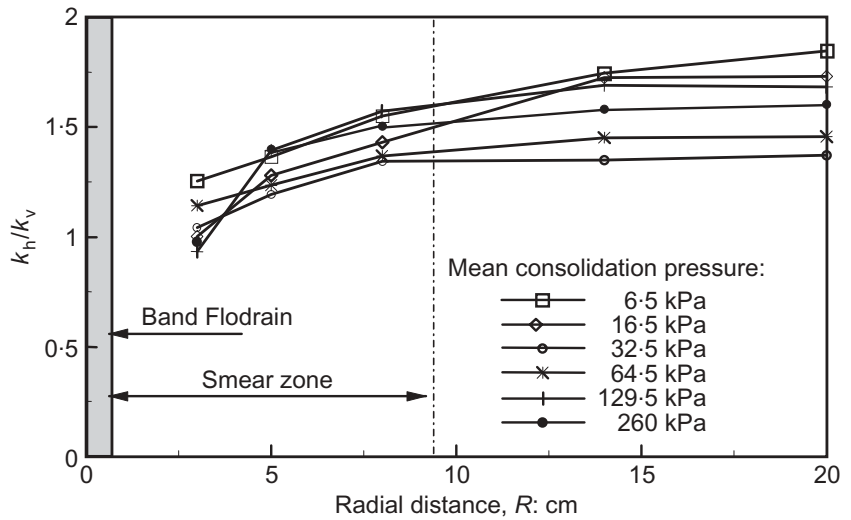

Fig. 7. Ratio of $k_{h} / k_{v}$ along the radial distance from the central drain (Indraratna and Redana, 1998)

Hokkaido to the Chugoku region in Japan. Bergado et al. (1991) conducted a thorough laboratory study on the development of the smear zone in soft Bangkok clay, and they reported that the ratio of the horizontal permeability coefficient of the undisturbed zone to that of the smear zone varied between 1.5 and 2, with an average of 1.75 . More significantly, the ratio $k_{\mathrm{h}}^{\prime} / k_{\mathrm{v}}^{\prime}$ was found to be almost unity within the smear zone, which is in agreement with results observed by the authors for a number of soft soils in the smear zone.

\section{Soil model and types of element}

The Cam-clay model has received wide acceptance, owing to its simplicity and accuracy in modelling soft clay behaviour. Utilising the critical-state concept based on the theory of plasticity in soil mechanics (Schofield and Wroth, 1968), the modified Cam-clay model was introduced to address the problems of the original Cam-clay model (Roscoe and Burland, 1968). The obvious difference between the modified Cam-clay model and the original Cam-clay model is the shape of the yield locus: that of the modified model is elliptical.

The finite-element software codes CRISP, SAGE-CRISP, ABAQUS and FLAC include the modified Cam-clay model, and these programs have been successfully used in the past for soft clay embankment modelling. The basic element types used in consolidation analysis are: the linear strain triangle (LST), consisting of six displacement nodes; threenoded linear strain bar (LSB) elements, with two-pore pressure nodes at either end and a sole displacement node in the middle; and the eight-noded LSQ elements, also having a linear pore pressure variation (Fig. 8). More details are given by Britto and Gunn (1987).

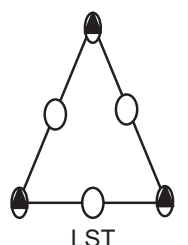

Pore pressure DOF
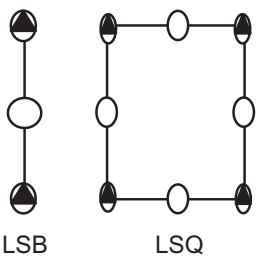

LSQ
Fig. 8. Types of element used in finite-element analysis: LST, linear strain triangle; LSB, linear strain bar; LSQ, (linear strain quadrilateral) 


\section{Drain efficiency by pore pressure dissipation}

In a comprehensive study, the performance of an embankment stabilised with vertical drains in Muar clay (Malaysia) was analysed using the modified Cam-clay model. The effectiveness of the prefabricated drains was evaluated according to the rate of excess pore pressure dissipation at the soil drain interface. Both single- and multi-drain (whole embankment) analyses were carried out to predict the settlement and lateral deformation beneath the embankment, employing a plane-strain finite-element approach. As explained in detail by Indraratna et al. (1994), for multi-drain analysis underneath the embankment the overprediction of settlement is more significant compared with the singledrain analysis. Therefore it was imperative to analyse more accurately the dissipation of the excess pore pressures at the drain boundaries at a given time.

The average undissipated excess pore pressures could be estimated by finite-element back-analysis of the settlement data at the centreline of the embankment. In Fig. 9, 100\% represents zero dissipation when the drains are fully loaded. At the end of the first stage of consolidation (that is, $2.5 \mathrm{~m}$ of fill after 105 days), the undissipated pore pressure has decreased from $100 \%$ to $16 \%$. For the second stage of loading, the corresponding magnitude decreases from $100 \%$ to $18 \%$ after a period of 284 days, during which the height of the embankment has already attained the maximum of $4.74 \mathrm{~m}$. It is clear that perfect drain conditions are approached only after a period of 400 days. An improved prediction of settlement and lateral deformation could be made when non-zero excess pore pressures at the drain interface were input into the finite-element model (FEM), simulating partially clogged conditions. The retarded excess pore pressure dissipation also represents the smear effect that contributes to decreased drain efficiency.

\section{Matching permeability and geometry}

Hird et al. $(1992,1995)$ presented a modelling technique in which the concept of permeability and geometry matching was applied to several embankments stabilised with vertical drains in Porto Tolle (Italy), Harlow (UK) and Lok Ma Chau (Hong Kong). The requirement for combination of permeability and geometry matching is given by the following equation (parameters defined earlier in Fig. 3):

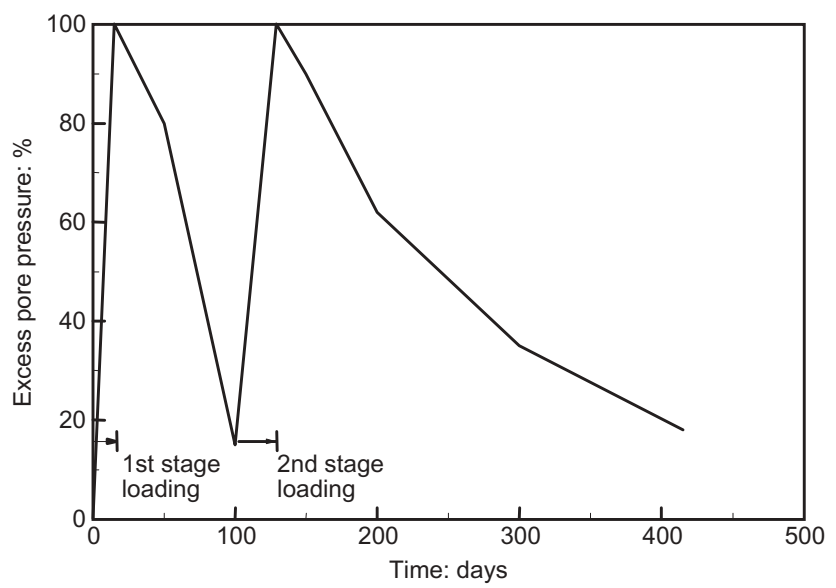

Fig. 9. Percentage of undissipated excess pore pressures measured at drain-soil interfaces due to smear effect and well resistance (Indraratna et al., 1994)

$$
\frac{k_{\mathrm{hp}}}{k_{\mathrm{h}}}=\frac{2 B^{2}}{3 R^{2}\left[\ln \left(\frac{R}{r_{\mathrm{s}}}\right)+\frac{k_{\mathrm{h}}}{k_{\mathrm{h}}^{\prime}} \ln \left(\frac{r_{\mathrm{s}}}{r_{\mathrm{w}}}\right)-0.75\right]}
$$

The effect of well resistance is independently matched by

$$
\frac{q_{\mathrm{z}}}{q_{\mathrm{w}}}=\frac{2 B}{\pi R^{2}}
$$

An acceptable prediction of settlements was obtained (Fig. $10)$, although the pore water pressure dissipation was more difficult to predict (Fig. 11). At Lok Ma Chau (Hong Kong), the settlements were significantly overpredicted, because the effect of smear was not considered, although the plane-strain model (Hird et al., 1992) allows the smear effect to be incorporated.

At Porto Tolle embankment, prefabricated vertical geodrains were installed on a $3.8 \mathrm{~m}$ triangular grid to a depth of $21.5 \mathrm{~m}$ below ground level. The embankment, which was constructed over a period of 4 months, had a height of $5.5 \mathrm{~m}$, a crest width of $30 \mathrm{~m}$, a length of over $300 \mathrm{~m}$, and a side slope of about 1 in 3 . The behaviour of soft clay was modelled using the modified Cam-clay theory. The results of single-drain analysis at the embankment centreline were considered. Typical results of the finite-element analysis are compared with observed data in Figs 10 and 11.

\section{Modelling of discharge capacity}

Chai et al. (1995) extended the method proposed by Hird et al. (1992) to include the effect of well resistance and

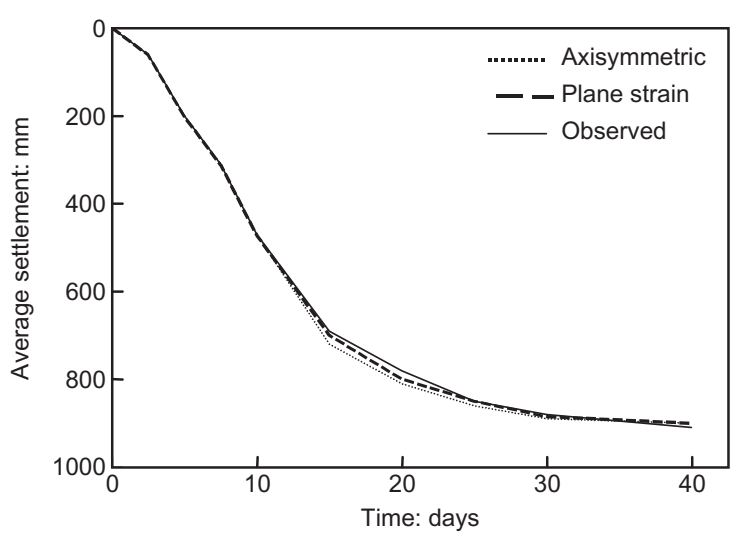

Fig. 10. Comparison of average surface settlement for Porto Tolle embankment (Hird et al., 1995) at embankment centreline

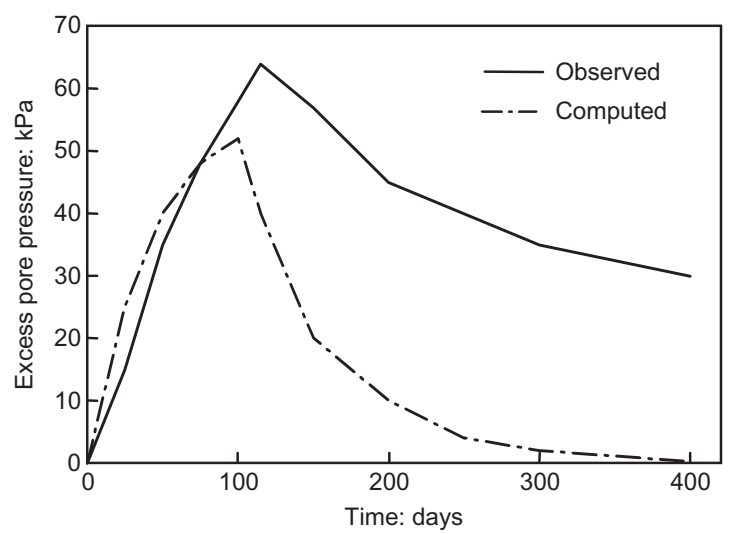

Fig. II. Comparison of excess pore pressure midway between the drains at mid-depth, for Porto Tolle embankment (Hird et al., 1995) 
clogging. Four types of analysis were presented, considering:

(a) no vertical drains

(b) embankment with vertical drains, and the discharge capacity of the drains increasing with depth

(c) drains with constant discharge capacity

(d) the same as (c) but assuming that the drains were clogged below $9 \mathrm{~m}$ depth.

The discharge capacity of the drain in plane strain for matching the average degree of horizontal consolidation is given by

$$
q_{\mathrm{wp}}=\frac{4 k_{\mathrm{h}} l^{2}}{3 B\left[\ln \left(\frac{n}{s}\right)+\frac{k_{\mathrm{h}}}{k_{\mathrm{s}}} \ln s-\frac{17}{12}+\frac{2 l^{2} \pi k_{\mathrm{h}}}{3 q_{\mathrm{wa}}}\right]}
$$

The analysis was refined using a single drain model $5 \mathrm{~m}$ long; both elastic and elasto-plastic approaches were used to predict its performance. Excellent agreement was obtained between the axisymmetric and plane-strain models, especially with varied discharge capacity, $q_{\mathrm{wp}}$, as shown in Fig. 12. For elastic analysis, well resistance matching also resulted in a more realistic excess pore water pressure variation (Fig. 13). The varied discharge capacity yielded a more uniform and closer match between axisymmetric and

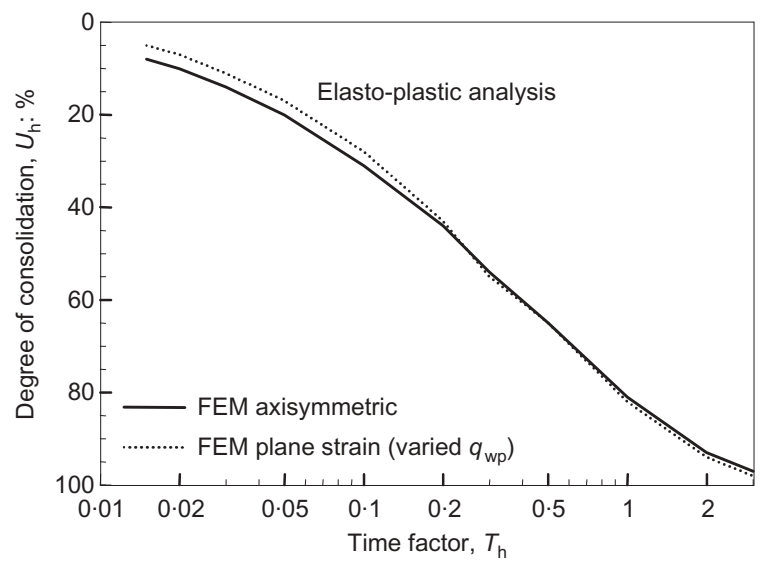

Fig. I2. Comparison of average degree of horizontal consolidation (Chai et al., 1995)

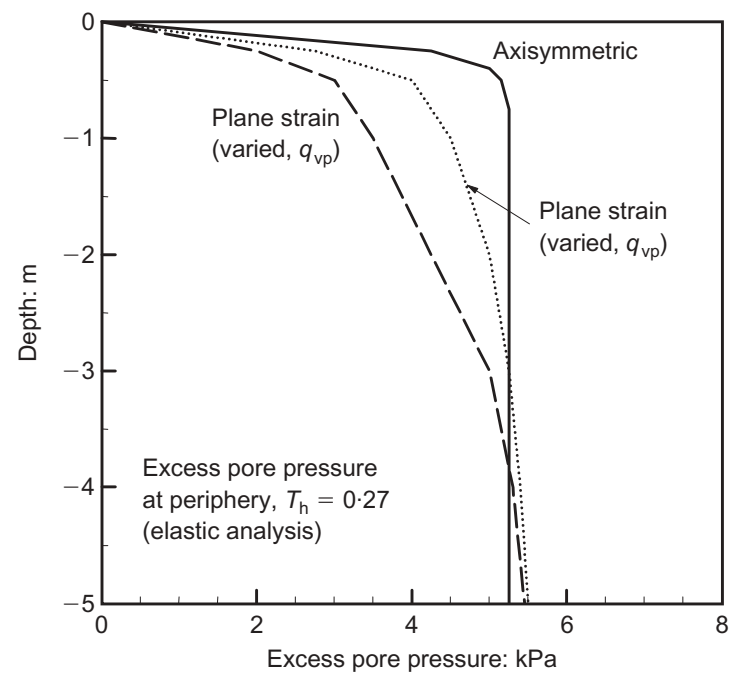

Fig. I3. Comparison of excess pore pressure variation with depth (Chai et al., 1995) plane-strain methods compared with the constant discharge capacity assumption. Chai et al. (1995) verified that accurate pore pressure predictions could be obtained only when both the smear effect $\left(k_{\mathrm{h}} / k_{\mathrm{v}}\right.$ ratio) and well resistance $\left(q_{\mathrm{w}}\right)$ were incorporated into the finite-element analysis.

\section{Applications in practice and field observation}

\section{Equivalent two-dimensional plane-strain analysis}

Single-drain analysis is sufficient to model the soil behaviour along the embankment centreline (symmetric geometry). However, a multi-drain analysis is required to consider the changing gravity load along the embankment width to predict the settlements and lateral displacements away from the centreline. In multi-drain analysis, two-dimensional plane-strain analysis is far less time-consuming than a true three-dimensional analysis dealing with a large number of axisymmetric vertical drains, which substantially affect the mesh complexity and corresponding convergence. An equivalent two-dimensional plane-strain model in multidrain finite-element analysis (Chai et al., 1995; Indraratna and Redana, 1997) gives acceptable predictions of settlements, pore pressures and lateral displacements. Details of successful two-dimensional multi-drain analyses for various case histories have been reported recently by Indraratna et al. (1992), Indraratna and Redana $(1999,2000)$ and Chai et al. (1995), among others.

\section{Pore pressure, settlements and lateral displacements}

Indraratna and Redana $(1995,1999,2000)$ analysed the performance of several test embankments using their twodimensional plane-strain model. Fig. 14 shows a typical subsoil profile, modified Cam-clay parameters and the effective stress conditions on the site. The unit weight of the weathered crust (compacted) is about $18 \mathrm{kN} / \mathrm{m}^{3}$, and the unit weight of the very soft clay is about $14.3 \mathrm{kN} / \mathrm{m}^{3}$ at a depth of $7 \mathrm{~m}$. A typical finite-element mesh employing multi-drain analysis is shown in Fig. 15, where the foundation is discretised into linear strain quadrilateral (LSQ) elements. For the PVD stabilised zone a finer mesh was employed, and each drain element includes the smear zone on either side of the drain. The locations of the instrumentation (inclinometers and piezometers) are shown in the mesh, with the measurement points conveniently placed on the element nodes. The embankment is built in four stages (that is, sequential construction). The equivalent plane-strain values were determined based on equations (14), (15) and (16). The minimum discharge capacity $\left(q_{\mathrm{w}}\right)$ of $40-60 \mathrm{~m}^{3} /$ year was estimated to model the settlements and pore water pressure dissipation, after a number of single-drain trials.

The measured and predicted settlements of a typical embankment are plotted in Fig. 16. The 'perfect drain' analysis (that is, no smear, complete pore pressure dissipation) overpredicts the measured data. The inclusion of the smear effect improves the accuracy of the settlement predictions. The inclusion of both smear and well resistance slightly underestimates the measured settlements. In this case the role of well resistance can be regarded as insignificant, in comparison with the smear effect.

The excess pore pressures along the centreline of a typical embankment at a depth of $2 \mathrm{~m}$ below the ground surface are plotted in Fig. 17. In the 'smear only' analysis, the pore 


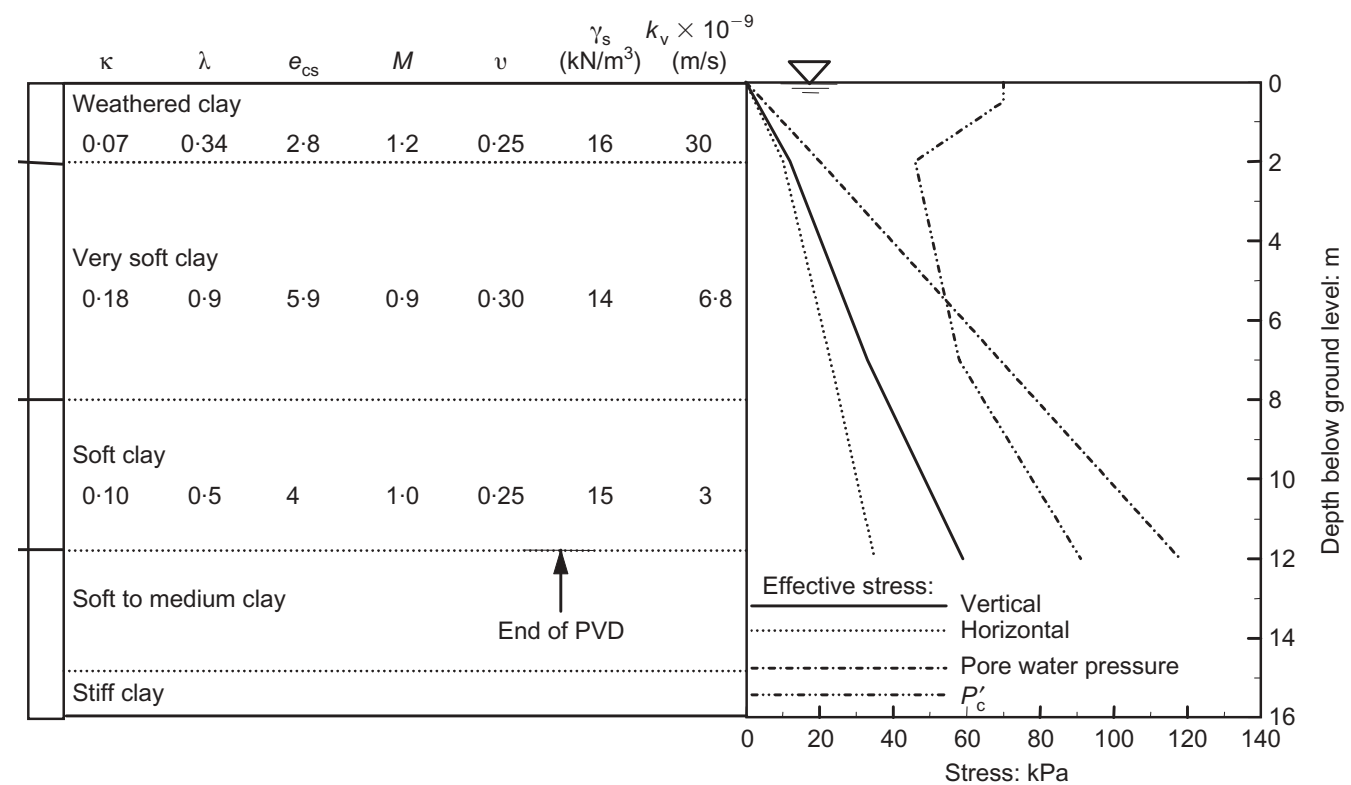

Fig. 14. Subsoil profile, Cam-clay parameters and stress condition used in numerical analysis, Second Bangkok International Airport, Thailand (Asian Institute of Technology, 1995)

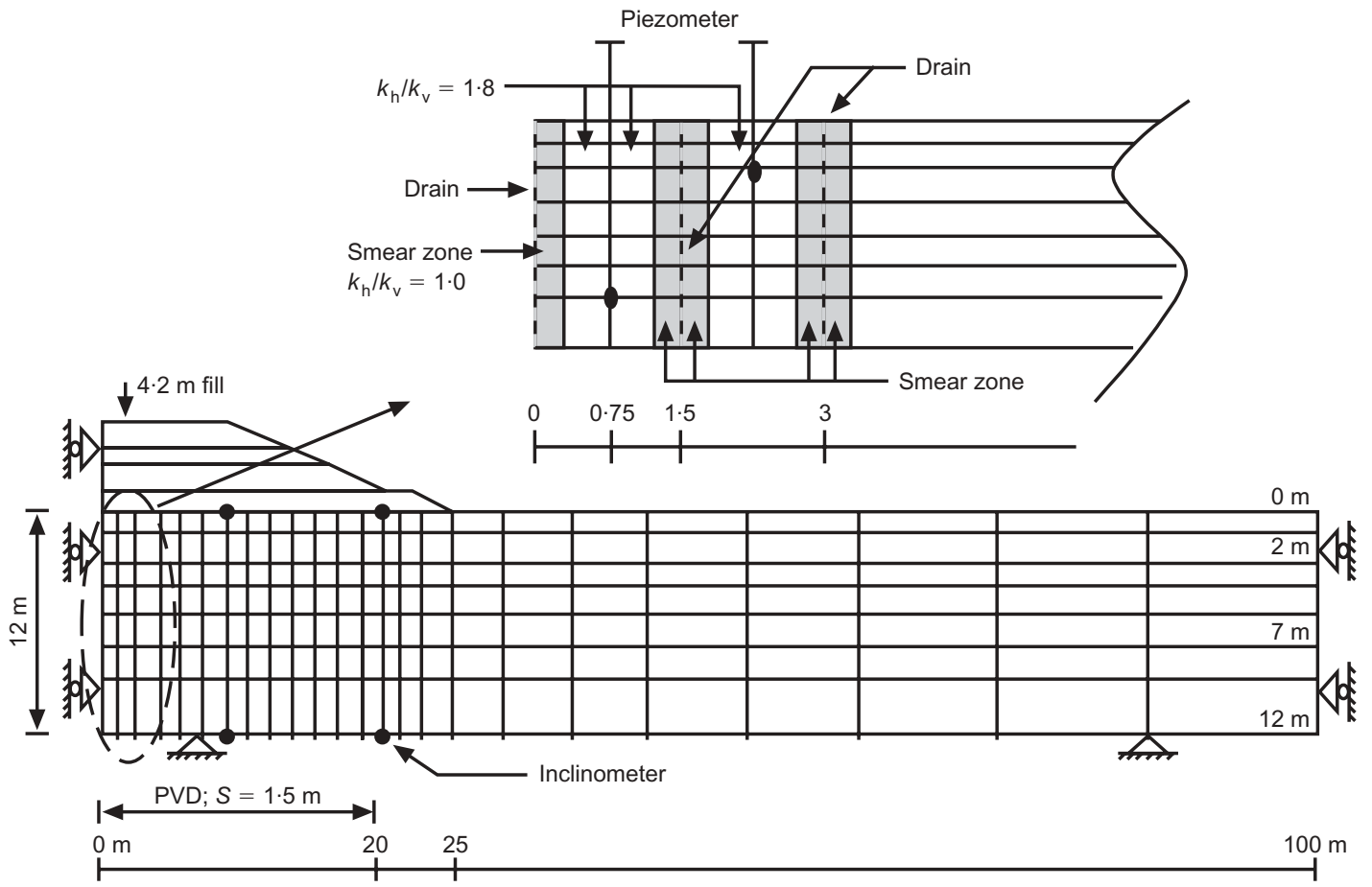

Fig. 15. Typical finite-element mesh of the embankment for plane-strain analysis (Indraratna and Redana, 2000)

water pressure increase is well predicted during stage 1 and stage 2 loading. Nevertheless, after stage 3 loading, the predicted pore pressure values are significantly smaller than the field data. The 'perfect drain' predictions, as expected, underestimate the measurements. Inclusion of the effects of both smear and well resistance in the FEM analysis gives a better prediction of pore water pressure dissipation for all stages of loading.

The prediction of settlement along the ground surface from the centreline of a typical embankment in Muar clay (after 400 days) is shown in Fig. 18. At the embankment centreline, the limited available data agree well with the settlement profile. Also, using the current plane-strain model, heave could be predicted beyond the toe of the embankment: that is, at about $42 \mathrm{~m}$ away from the centreline. Note that the prediction of heave is usually difficult unless the numerical model is functioning correctly.

Observed and computed lateral deformation for the inclinometer $23 \mathrm{~m}$ away from the centreline of the Muar clay embankment are shown in Fig. 19. The lateral displacements at 44 days after loading are well predicted, because the effects of smear and well resistance are incorporated. The 'perfect drain' condition, as expected, gives the least lateral displacement. The predicted lateral yield for the condition of 'no drains' is also plotted for comparison. It is verified that the presence of PVDs is capable of reducing the lateral 


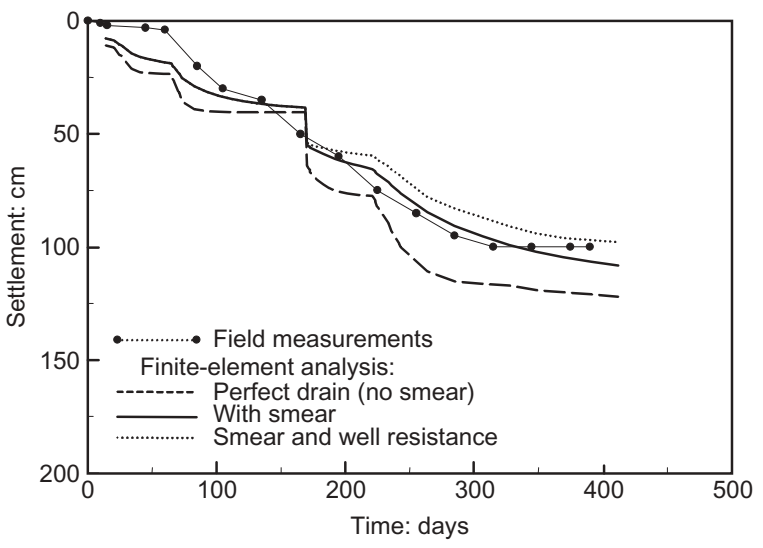

Fig. 16. Surface settlement at the centreline for embankment TSI, Second Bangkok International Airport (Indraratna and Redana, 2000)

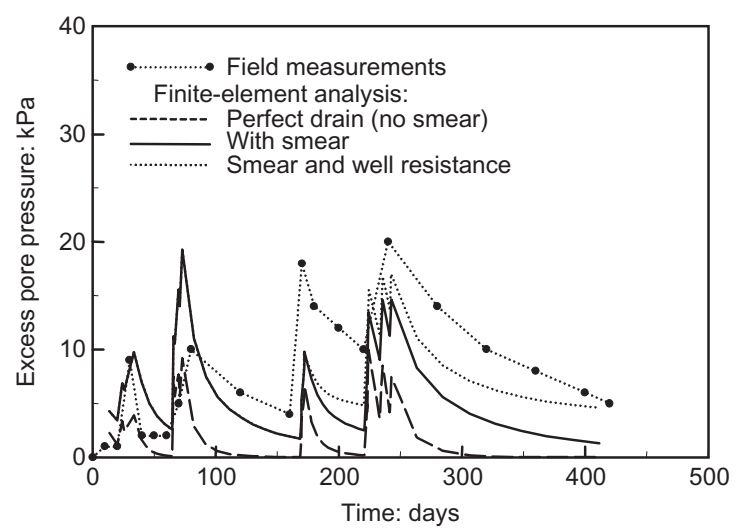

Fig. 17. Variation of excess pore water pressures at $2 \mathrm{~m}$ depth below ground level at the centreline for embankment TSI (Indraratna and Redana, 2000)

movement of soft clay significantly, as long as the spacing of the drains is appropriate and pore pressure dissipation is not prevented by clogging or excessive smear.

\section{Lateral displacement as a stability factor}

Vertical drains accelerate the settlement, but they decrease the lateral displacement of soft clay foundations (Fig. 19). The effect of PVDs on lateral displacement is a function of drain spacing and the extent of smear. Indraratna et al.

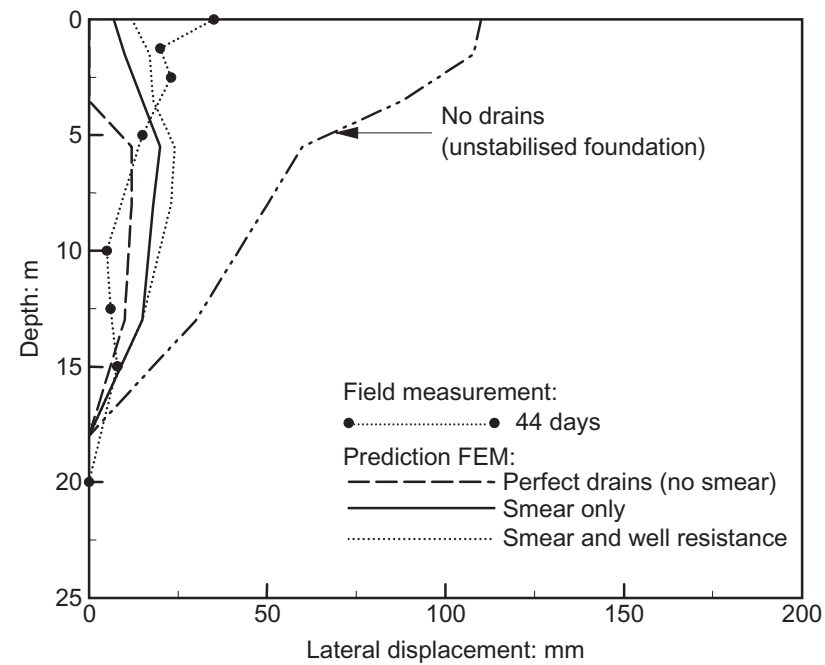

Fig. 19. Lateral displacement profiles at $23 \mathrm{~m}$ away from centreline of Muar clay embankment after 44 days (Indraratna and Redana, 2000)

(2001) have shown that the ratio of lateral deformation to maximum settlement, $\alpha$, and the ratio of lateral deformation to maximum fill height, $\beta$, can be considered as stability indicators for soft clays improved by vertical drains. Figs 20 and 21 show a comparison between sand compaction piles (SCPs) and PVDs installed in Muar clay, Malaysia. The values of indicators $\alpha$ and $\beta$ for the PVDs are considerably less than for the SCPs. This is because the SCPs were installed at a much larger spacing of $2.2 \mathrm{~m}$, whereas the PVDs were installed at a spacing of $1.3 \mathrm{~m}$. Although SCPs have a much higher stiffness than PVDs, the spacing of $2.2 \mathrm{~m}$ is excessive for effectively curtailing the lateral displacement. This demonstrates that the stiffness of vertical drains is of secondary importance in comparison with the need for appropriate spacing in controlling lateral deformation.

\section{Application of vacuum pressure}

Kjellman (1952) proposed vacuum-assisted preloading to accelerate the rate of consolidation. Since then, the use of vacuum preloading with PVDs has been discussed in a number of studies (Holtz, 1975; Choa, 1989; Bergado et al., 1998). The application of vacuum pressure can compensate for the effects of smear and well resistance, which are often inevitable in long PVDs.

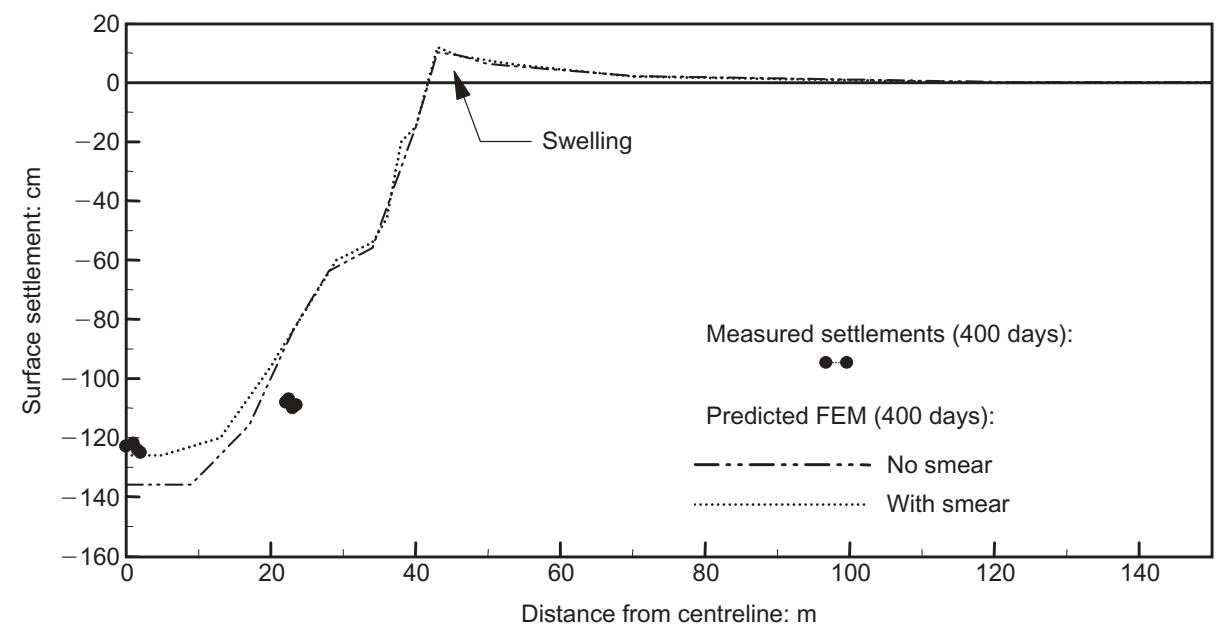

Fig. 18. Surface settlement profiles after 400 days, Muar clay, Malaysia (Indraratna and Redana, 2000) 


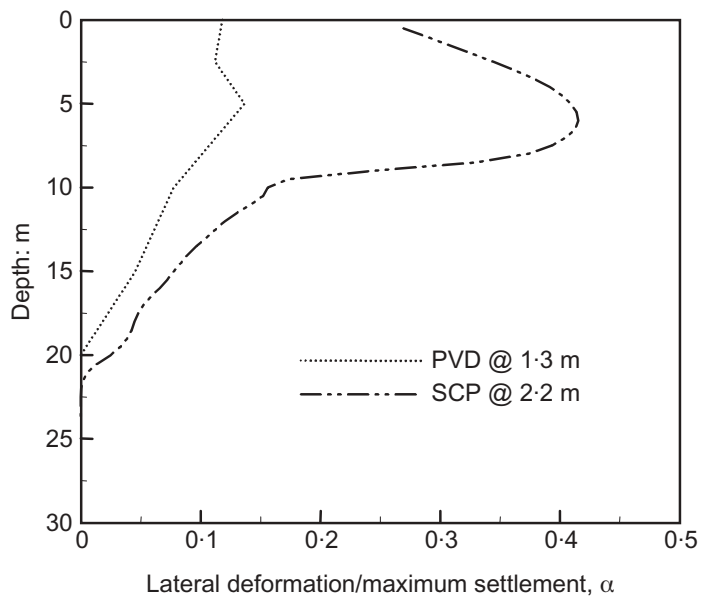

Fig. 20. Normalised lateral deformation with respect to maximum settlement (Indraratna et al., 200I)

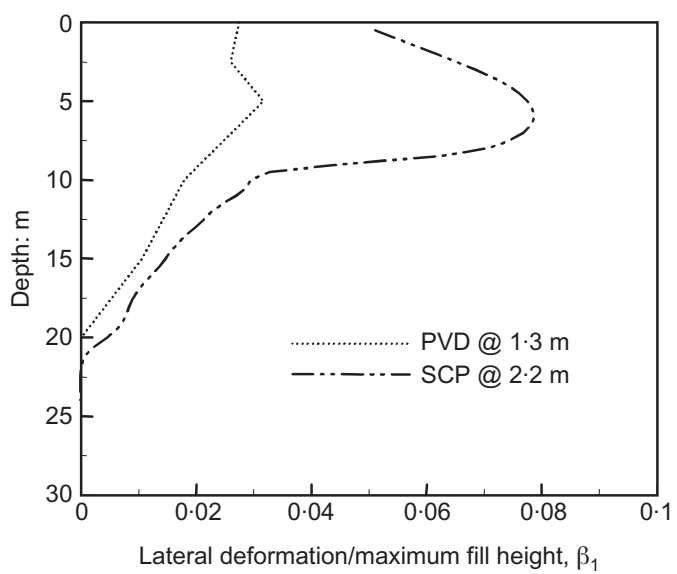

Fig. 2I. Normalised lateral deformation with respect to maximum fill height (Indraratna et al., 200I)

Finite-element analysis was applied by Bergado et al. (1998) to analyse the performance of embankments stabilised with vertical drains, where combined preloading and vacuum pressure were utilised at the Second Bangkok International Airport site. A simple approximate method for modelling the effect of PVDs as proposed by Chai and Miura (1997) was incorporated in this study. PVDs increase the mass permeability in the vertical direction. Consequently, it is possible to establish a value of the permeability of the natural subsoil and the radial permeability towards the PVDs. This equivalent vertical permeability $\left(K_{\mathrm{ve}}\right)$ is derived based on the equal average degree of consolidation.

The approximate average degree of vertical consolidation, $U_{\mathrm{v}}$, is given by

$$
U_{\mathrm{v}}=1-\exp (-3 \cdot 54) T_{\mathrm{v}}
$$

where $T_{\mathrm{v}}$ is the dimensionless time factor.

The equivalent vertical permeability, $K_{\mathrm{ve}}$, can be expressed by

$$
K_{\mathrm{ve}}=\left(1+\frac{2 \cdot 26 L^{2} K_{\mathrm{h}}}{F D_{\mathrm{e}}^{2} K_{\mathrm{v}}}\right) K_{\mathrm{v}}
$$

where

$$
F=\ln \left(\frac{D_{\mathrm{e}}}{d_{\mathrm{w}}}\right)+\left(\frac{K_{\mathrm{h}}}{K_{\mathrm{s}}}-1\right) \ln \left(\frac{d_{\mathrm{s}}}{d_{\mathrm{w}}}\right)-\frac{3}{4}+\frac{\pi 2 L^{2} K_{\mathrm{h}}}{3 q_{\mathrm{w}}}
$$

In equation (26), $D_{\mathrm{e}}$ is the equivalent diameter of a unit PVD influence zone, $d_{\mathrm{s}}$ is the equivalent diameter of the disturbed zone, $d_{\mathrm{w}}$ is the equivalent diameter of PVD, $K_{\mathrm{h}}$ and $K_{\mathrm{s}}$ are the undisturbed and disturbed horizontal permeability of the surrounding soil respectively, $L$ is the length for oneway drainage, and $q_{\mathrm{w}}$ is the discharge capacity of PVD. The effects of smear and well resistance have been incorporated in the derivation of the equivalent vertical permeability.

Two full-scale test embankments, TV1 and TV2, each with a base area of $40 \mathrm{~m} \times 40 \mathrm{~m}$, were analysed by Bergado et al. (1998). The performance of embankment TV2 with vacuum preloading, compared with the embankment at the same site without vacuum preloading, showed an acceleration in the rate of settlement of about $60 \%$, and a reduction in the period of preloading by about 4 months.

\section{Conclusion}

The two-dimensional plane-strain theory for PVDs installed in soft clay has been discussed, and a multi-drain analysis has been conducted for several embankments stabilised with PVDs. The results show that the inclusion of both smear and well resistance improves the accuracy of the predicted settlements, pore pressures and lateral deformations. For short drains, normally less than $20 \mathrm{~m}$, the inclusion of well resistance alone does not affect the computed results significantly. The 'perfect drain' analysis overpredicts the settlements and underpredicts the pore pressures. Predictions of surface settlement are generally feasible, but accurate predictions of lateral displacement are not an easy task by two-dimensional plane-strain analysis. The prediction of lateral deformation is acceptable when both smear and well resistance are included in the analysis. It is also found that adoption of the appropriate value of discharge capacity of the PVD improves the accuracy of the predicted lateral displacement. This is because the drains having a small discharge capacity tend to increase lateral movement, as well as retarding the pore water pressure dissipation. The spacing of the drains is another factor that significantly affects the lateral displacement.

The possible air gap between drain and soil caused during mandrel withdrawal can affect the pore pressure dissipation, and hence the associated soil deformation. Based on preliminary studies, it has been verified that an unsaturated interface can significantly reduce the rate of consolidation. The application of vacuum pressure is an effective way of accelerating the rate of consolidation, especially for long PVDs that are vulnerable to smear and well resistance. The use of a traditional earth fill preloading combined with vacuum pressure can shorten the duration of preloading, especially in soft clays with low shear strength. However, the modelling aspects of vacuum pressure and its effect on soil consolidation via PVDs warrant further study and research.

Finally, it seems that the proper use of the two-dimensional plane-strain model in a multi-drain finite-element analysis is acceptable, based on computational efficiency in a PC environment. The behaviour of each PVD is axisymmetric (truly three-dimensional), but it is currently impossible to model, in three dimensions, a large number of PVDs in a big embankment site without making simplifications. In this context, the equivalent plane-strain model with further refinement will continue to offer a sufficiently accurate predictive tool for design, performance verification and back-analysis. 


\section{Acknowledgements}

The authors gratefully acknowledge the continuing support of Professor Balasubramaniam, formerly at AIT Bangkok (currently at NTU, Singapore), in providing muchneeded field data for various past and present studies. The assistance of the Malaysian Highway Authority is also appreciated. The various efforts of past research students who worked under Professor Indraratna in soft clay improvement are gratefully appreciated.

\section{References}

Asian Institute of Technology (1995) The Full Scale Field Test of Prefabricated Vertical Drains for the Second Bangkok International Airport (SBIA). AIT, Bangkok, Final Report, Division of Geotechnical and Transportation Engineering.

BARron R. A. (1948) Consolidation of fine-grained soils by drain wells. Transactions of the American Society of Civil Engineers, 113, paper 2346, 718-724.

Bergado D. T., Asakami H., Alfaro M. C. and Balasubramaniam A. S. (1991) Smear effects of vertical drains on soft Bangkok clay. Journal of Geotechnical Engineering, ASCE, 117, No. 10, 1509-1530.

Bergado D. T., Chai J. C., Miura N. and Balasubramaniam A. S. (1998) PVD improvement of soft Bangkok clay with combined vacuum and reduced sand embankment preloading. Geotechnical Engineering Journal 29, No. 1, 95-122.

Britto A. M. and GunN M. J. (1987) Critical State Soil Mechanics via Finite Elements. Ellis Horwood, Chichester.

Chai J. C. and Miura N. (1997) Method of modeling vertical drain improved subsoil. Proceedings of the China-Japan Joint Symposium on Recent Developments of Theory and Practice in Geotechnology, Shanghai, China, pp. 1-8.

Chai J. C., Miura N., Sakajo S. and Bergado D. (1995) Behaviour of vertical drain improved subsoil under embankment loading. Journal of Soil and Foundations, 35, No. 4, 49-61.

ChoA V. (1989) Drains and vacuum preloading pilot test. Proceedings of the 12th International Conference on Soil Mechanics and Foundation Engineering, Rio de Janeiro, 1347-1350.

Hansbo S. (1979) Consolidation of clay by band-shaped prefabricated drains. Ground Engineering, 12, No. 5, 16-25.

Hansbo S. (1981) Consolidation of fine-grained soils by prefabricated drains. Proceedings of the 10th International Conference on Soil Mechanics and Foundation Engineering, Stockholm, 3, 677-682.

Hansbo S. (1987) Design aspects of vertical drains and lime column installation. Proceedings of the 9th Southeast Asian Geotechnical Conference, 2, No. 8, 1-12.

Hird C. C., Pyrah I. C. and Russell D. (1992) Finite element modelling of vertical drains beneath embankments on soft ground. Géotechnique, 42, No. 3, 499-511.

Hird C. C., Pyrah I. C., Russell D. and Cinicioglu F. (1995) Modeling the effect of vertical drains in two-dimensional finite element analyses of embankments on soft ground. Canadian Geotechnical Journal, 32, 795-807.

Holtz R. D. (1975) Preloading by vacuum: current prospects. Transportation Research Record, No. 548, pp. 26-69.

Holtz R. D., Jamiolkowski M., Lancellotta R. and Pedroni S. (1991) Prefabricated Vertical Drains: Design and Performance. Butterworth-Heinemann, CIRIA Ground Engineering Report: Ground Improvement.

Holtz R. D., Jamiolkowski M., Lancellotta R. and Pedroni S (1988) Behaviour of bent prefabricated vertical drains. Proceedings of the 12th International Conference on Soil Mechanics and Foundation Engineering, Rio de Janeiro, 3, 1657-1660

INDRARATNA B. and REDANA I. W. (1995) Large-scale, radial drainage consolidometer with central drain facility. Australian Geomechanics, 29, 103-105.

IndRARATNA B. and RedANA I. W. (1997) Plane strain modeling of smear effects associated with vertical drains. Journal of Geotechnical Engineering, ASCE, 123, No. 5, 474-478.

INDRARATNA B. and REDANA I. W. (1998) Laboratory determination of smear zone due to vertical drain installation. Journal of
Geotechnical Engineering, ASCE, 124, No. 2, 180-184.

IndraRATnA B. and RedAnA I. W. (1999) Closure: Plane strain modeling of smear effects associated with vertical drains. Journal of Geotechnical and Geoenvironmental Engineering, ASCE, 125, No. 1, 96-99.

IndRARATNA B. and REDANA I. W. (2000) Numerical modeling of vertical drains with smear and well resistance installed in soft clay. Canadian Geotechnical Journal, 37, 132-145.

INDRARATNA B., Balasubramaniam A. S. and BaLachandRan S (1992) Performance of test embankment constructed to failure on soft marine clay. Journal of Geotechnical Engineering, ASCE, $118,12-33$

IndRaRATNA B., Balasubramaniam A. S. and RatnayaKe P. (1994) Performance of embankment stabilized with vertical drains on soft clay. Journal of Geotechnical Engineering, ASCE, 120, No. 2, 257-273.

Indraratna B., Bamunawita C., Redana I. W. and BalasubramaNIAM A. S. (2001) Modeling of vertical drains in soft clay. Proceedings of the 3rd International Conference on Soft Soil Engineering, Hong Kong, 329-338.

JamiolkowsKi M. and Lancellotta R. (1981) Consolidation by vertical drains: uncertainties involved in prediction of settlement rates (Panel discussion). Proceedings of the 10th International Conference on Soil Mechanics and Foundation Engineering, Stockholm, 1, 345-451.

JAMiolKowsKi M. and LANCellotta R. (1984) Embankment on vertical drains: pore pressure during construction. Proceedings of the International Conference on Case Histories in Geotechnical Engineering, St Louis, Vol. 1, pp. 275-278.

KJELLMAN W. (1948) Accelerating consolidation of fine grain soils by means of cardboard wicks. Proceedings of the 2nd International Conference on Soil Mechanics and Foundation Engineering, 2, 302-305.

KJellman W. (1952) Consolidation of clay soil by means of atmospheric pressure. Proceedings of the Conference on Soil Stabilization, MIT, Cambridge, pp. 258-263.

OnOue A. (1988) Consolidation by vertical drains taking well resistance and smear into consideration. Journal of Soils and Foundations, 28, No. 4, 165-174

Onoue A., Ting N. H., Germaine J. T. and Whitman R. V. (1991) Permeability of disturbed zone around vertical drains. Proceedings of the ASCE Geotechnical Engineering Congress, Colorado, pp. 879-890.

Pradhan T. B. S., Imai G., Murata T., Kamon M. and Suwa S. (1993) Experiment study on the equivalent diameter of a prefabricated band-shaped drain. Proceedings of the 11th Southeast Asian Geotechnical Conference, 1, 391-396.

Redana I. W. (1999) Efficiency of Vertical Drains Installed in Soft Clay with Special Reference to Smear Effect. PhD thesis, University of Wollongong, Australia.

Richart F. E. Jr (1959) A review of the theories for sand drains. Journal of Soil Mechanics and Foundation Engineering, ASCE, 83, No. SM3, 1301(1-38).

Rixner J. J., Kraemer S. R. and Smith A. D. (1986) Prefabricated Vertical Drains, Vols I, II and III: Summary of Research Report: Final Report. Federal Highway Administration, Washington DC, Report No. FHWA-RD-86/169.

Roscoe K. H. and Burland J. B. (1968) On the generalized stressstrain behaviour of wet clay. In Engineering Plasticity, Cambridge University Press, Cambridge, pp. 535-609.

Schofield A. N. and Wroth C. P. (1968) Critical State Soil Mechanics. McGraw Hill, London.

Shogaki T., Moro H., Masaharu M., Kaneko M., Kogure K. and SudHo T. (1995) Effect of sample disturbance on consolidation parameters of anisotropic clays. Proceedings of the International Symposium on Compression and Consolidation of Clayey Soils, Hiroshima, Vol. 1, pp. 561-566.

Tavenas F., Jean P. and Leroueil S. (1983) The permeability of natural soft clays, Part 2: Permeability characteristics. Canadian, Geotechnical Journal, 20, 645-660.

Discussion contributions on this paper should reach the editor by 1 February 2004 